\title{
Species size distributions of benthic and pelagic Metazoa: evidence for interaction?
}

\author{
R. M. Warwick, N. R. Collins, J. M. Gee \& C. L. George \\ NERC Institute for Marine Environmental Research, Prospect Place, The Hoe, Plymouth PL1 3DH, United Kingdom
}

\begin{abstract}
The benthic metazoan fauna at Station CS2 in the Celtic Sea has the familiar bimodal pattern of species size distribution, with a meiofaunal mode at $0.63 \mu \mathrm{g}$ dry weight, a macrofauna mode at $2.03 \mathrm{mg}$ and the trough between them at $60 \mu \mathrm{g}$. The pelagic community, on the other hand, has its centre of distribution corresponding with the position of the benthic trough. Differences in taxonomic composition cannot explain this pattern since within a single taxon, as exemplified by the Copepoda, there are marked size differences between the benthic and planktonic assemblage. Of the possible mechanisms of benthic/pelagic coupling which might influence species size distributions, interactions between macrobenthic larvae and holoplankton and the influence of the pelagic community on the nature of the benthic food supply are considered potentially important. Planktotrophic larvae of benthic macrofauna avoid competition with similarly sized meiobenthic organisms but settle when they reach the size of the holoplankton. Thus resource partitioning on a size basis between these larvae and the holoplankton may occur. Benthic communities enriched with non-phytoplankton organic material show size convergence of meiofauna and macrofauna, their species size distribution being similar to that of pelagic communities. This may result from a relaxation of benthic/pelagic interaction
\end{abstract}

\section{INTRODUCTION}

The distributions of adult body size of benthic species in communities from temperate Shelf waters have been shown to have a highly conservative bimodal pattern with a peak in the number of meiofaunal species at a dry body weight of $0.64 \mu \mathrm{g}$, a macrofauna peak at $3.2 \mathrm{mg}$ and a trough between them at $45 \mu \mathrm{g}$ (Warwick 1984). Warwick proposed that meiofauna and macrofauna comprise 2 separate evolutionary units with internally coherent life history and feeding characteristics, compromise traits being either non-viable or disadvantageous. Because many of these size-related traits have evolved under the pressure of relative confinement to a substrate, intuitively one might expect that pelagic communities would not conform to this bimodal pattern. No species size distributions have hitherto been determined for pelagic communities to compare with these benthic data, although pelagic biomass spectra are well documented (Sheldon et al. 1972). Schwinghamer (1985) has assembled data on benthic and pelagic biomass spectra which indicate that, in Shelf waters, a series of pelagic biomass peaks coincide with benthic troughs, and vice versa. He suggested that this is indicative of benthic/pelagic coupling, although the exact nature of the interaction remains unclear. In the present paper we have determined the species size distribution pattern for the entire metazoan fauna at a station in the Celtic Sea, and we assess these data in terms of possible size-related mechanisms of interaction.

\section{METHODS}

Samples were collected at Celtic Sea Station CS2 $\left(50^{\circ} 30.0^{\prime} \mathrm{N}, 7^{\circ} 00.0^{\prime} \mathrm{W}\right)$, between the Isles of Scilly and southern Ireland, at a water depth of $106 \mathrm{~m}$, between 2 and 6 July 1985. The bottom sediment, like that of most of the Celtic Sea, is of fine muddy sand with a median particle diameter of $143 \mu \mathrm{m}$ and $20.1 \%$ silt/clay.

The benthos was sampled by 8 replicate $0.25 \mathrm{~m}^{2}$ USNEL deep-sea box cores (Hessler \& Jumars 1974) which penetrated far enough into the sediment for the collection of large deep-burrowing macrofauna, and 8 replicate $5.7 \mathrm{~cm}$ internal diameter Craib cores (Craib 1965) to ensure undisturbed collection of small surface-living animals. Extraction of animals from the sediment followed the methodologies of McIntyre \& 
Warwick (1985), using $0.5 \mathrm{~mm}$ meshed sieves for the box cores and $63 \mu \mathrm{m}$ sieves for the Craib cores.

The following series of plankton samples was collected using a variety of mesh sizes, net diameters and towing speeds, (1) Four $0.5 \mathrm{~h}$ undulating (to near bottom) hauls with an unenclosed $76 \mathrm{~cm}$ Lowestoft sampler (Beverton \& Tungate 1967, Harding \& Arnold 1971), mesh $280 \mu \mathrm{m}$, towed at 5 knots. (2) Two $1 \mathrm{~h}$ undulating hauls with a $2 \mathrm{~m}$ ring net, $10 \mathrm{~mm}$ mesh, towed at 3 to 4 knots, and one similar haul using a $2 \mathrm{~m}$ square framed net. (3) Two $0.5 \mathrm{~h}$ undulating hauls with a $1.3 \mathrm{~m}$ ring net, $1 \mathrm{~mm}$ mesh, towed at 2 knots. (4) Two $0.75 \mathrm{~h}$ hauls with a $0.5 \mathrm{~m}$ ring net, $53 \mu \mathrm{m}$ mesh, drifted in the current with the ship stationary. All samples were preserved in buffered $4 \%$ formalin.

Adult body weights of each benthic species were determined as described by Warwick (1984); dry weights of adult pelagic species were determined by direct weighing on balances of appropriate sensitivity, or for some of the smaller copepods from volume calculations using scale models in plasticine (Warwick \& Gee 1984). The same conversion factors from volume to dry weight have been used for all benthic and pelagic species (Warwick 1984), so that the terms 'weight' and 'size' are used interchangeably in this paper. Species were assigned to $\times 2$ geometric size classes for the purposes of data presentation (Warwick 1984); Class 30 contains animals of 5 to $10 \mathrm{~g}$ dry weight, which with successive halvings produces Class 0 of 4.65 to $9.3 \mathrm{ng}$. Curve fitting and parameter estimation follow the methods of Clarke (1984).

\section{RESULTS}

The benthic adult body size distribution follows the familiar bimodal pattern of 2 separate log-normal curves (Fig. 1). The meiofauna peak is at size Class No. 6.49 ( $\equiv 0.63 \mu \mathrm{g})$, the macrofauna peak at Class No. 18.15 ( $\equiv 2.03 \mathrm{mg}$ ) and the trough between them at Class No. $13.08(\equiv 60 \mu \mathrm{g})$. The positions of the peaks correspond closely with average values determined by Warwick (1984) for a variety of benthic communities (meiofauna mode at $0.64 \mu \mathrm{g}$ and macrofauna at $3.2 \mathrm{mg}$ ). The position of the trough is at the upper end of the size range previously encountered (average = $45 \mu \mathrm{g})$. This is due to the much higher number of meiofauna species found at Stn CS2 relative to the other communities previously studied (e.g. 88 nematode species, 66 harpacticoid copepods, 6 kinorhynchs), whereas the macrofauna do not show this enhanced species richness. The position of the trough is a complex function of the positions and heights of the peaks and their confidence intervals and, whilst the meiofaunal curve at Stn CS2 has a peak

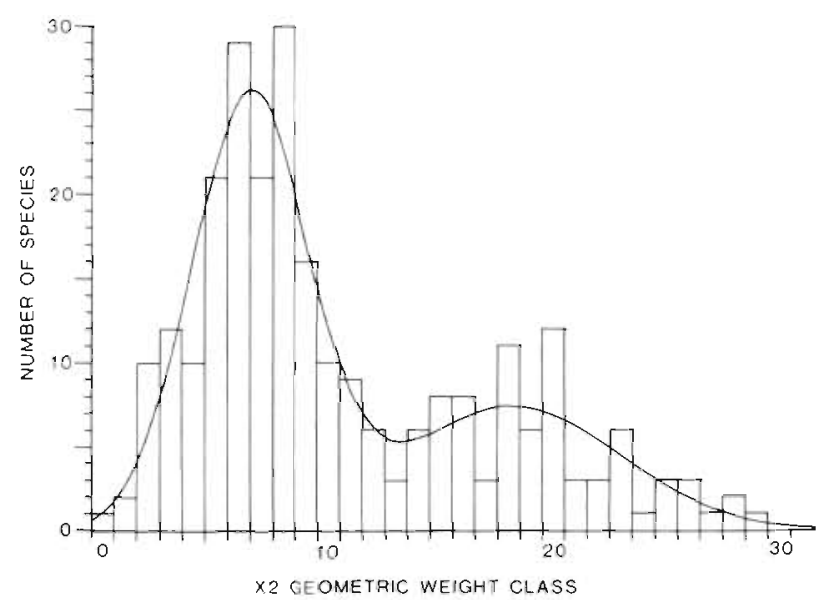

Fig. 1. Histogram of benthic species body size distribution at Stn CS2, with fitted bimodal curve

in the same position as, for example, a benthic community at $80 \mathrm{~m}$ depth off the coast of Northumberland, with similar $95 \%$ confidence intervals, the relatively greater height of the Stn CS2 curve pushes the trough further to the right.

The adult body size distribution for the pelagic community is compared with the benthic curve in Fig. 2. There are far fewer species in the pelagic community and it is therefore inappropriate to fit a theoretical distribution to the histogram. However, it is clear that the centre of this distribution is at a size which closely corresponds with the trough in the benthic curve, with a few species extending as a tail across the macrobenthic size range. Pelagic species in the trough region are principally copepods and cladocerans, and those in the macrobenthic range are medusae, euphausids and Sagitta spp.

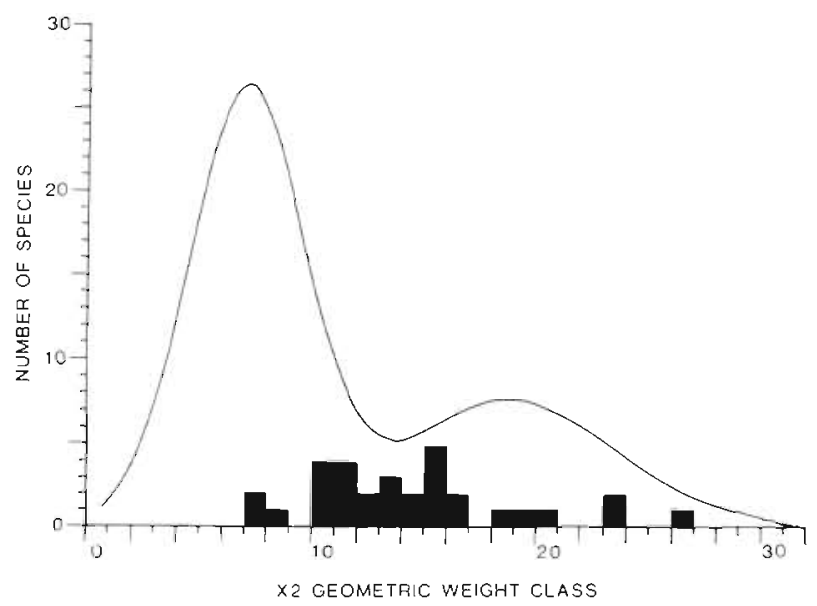

Fig. 2. Histogram of pelagic species body size distribution at Stn CS2 compared with bimodal benthic curve from Fig. 1 


\section{DISCUSSION}

\section{Benthic/pelagic interaction}

The exact correspondence of a peak in the pelagic species size distribution with a trough in the benthic species size distribution prompts speculation about possible interactions between the 2 systems. First we will consider the possibility that this correspondence is pure coincidence.

The composition of benthic and pelagic communities in terms of higher taxonomic groups is very different, which could account for the differences in species size distributions. However, if we compare a single taxon, the Copepoda, which is abundant in both realms, the size difference is still striking (Fig. 3). The constraints

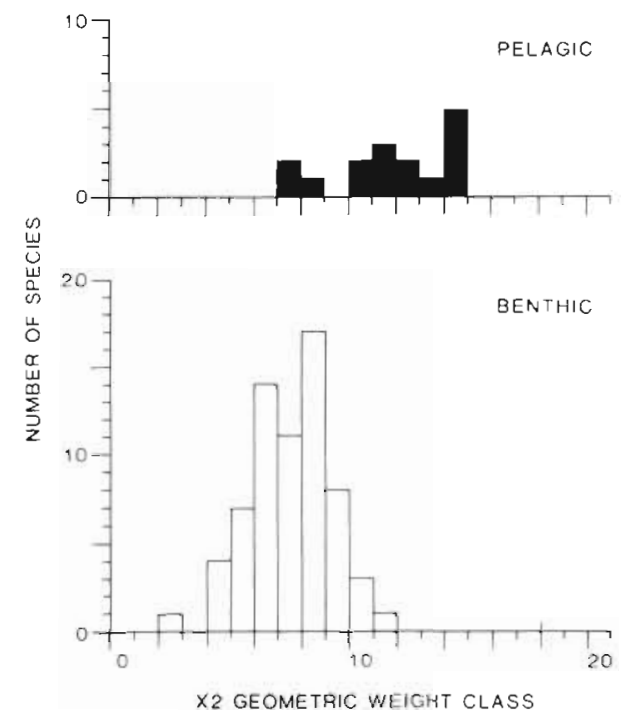

Fig. 3. Histograms comparing size distributions of pelagic and benthic copepod species at Stn CS2

on body size relative to the size of food particles encountered by planktonic suspension feeding copepods at low Reynolds number (Koehl \& Strickler 1981) do not apply to benthic copepods which feed from solid surfaces. Thus, although there are possible explanations for the relative paucity of small planktonic species, intuitively there is no reason why large species should not be equally abundant in the benthos as in the plankton. Furthermore, as we will show below, there are conditions under which the benthic copepod assemblage can become dominated by many large species. In short, there seems to be no adequate explanation for the pelagic species size distribution which does not invoke some form of interaction with the benthos

We can envisage a number of possible mechanisms of interaction between the benthic and pelagic systems which might contribute to the complimentary species size distribution patterns:

(1) Meiobenthic species in shallow water are dispersed as adults resuspended in the water column (Palmer 1984, Palmer \& Gust 1985) and may compete with the holoplankton for smaller-sized food particles. This is unlikely since meiobenthic organisms have feeding mechanisms designed to remove food particles from surfaces, and so would be unable to feed whilst in suspension. Furthermore, in all the zooplankton samples examined from the Celtic Sea, no meiobenthic species were ever encountered.

(2) Vertical migration into the water column by macrobenthic species, e.g. Cumacea, might result in similar competition for larger food particles. This is again unlikely since cumaceans comprise an insignificant component of the benthic biomass in the Celtic Sea, and predominantly benthic taxa were not found in any of the plankton hauls.

(3) The majority of macrobenthic species has planktonic larvae, the so-called meroplankton, which may constitute a substantial fraction of the total zooplankton biomass, for example $58 \%$ averaged over the year in the outer parts of the Bristol Channel (Williams \& Collins 1986). Resource partitioning between these 2 components might therefore be an important mode of benthic/pelagic interaction, and will be discussed in more detail below.

(4) Since the pelagic and benthic communities are ultimately dependent on the same primary food resource, phytoplankton, the possible modification of this resource by the pelagic community before it settles to the bottom provides a mechanism potentially modifying the pattern of species size distribution in the benthos.

\section{Interaction between macrobenthic larvae and holoplankton}

Macrobenthic species having planktotrophic larvae produce eggs that fall within the size distribution of adult meiobenthic species (Fig. 4). We have estimated this size distribution by calculating egg volumes from data given by Thorson (1946) for the macrobenthos of Oresund, which is a good representation of Shelf species from northern Europe, and assuming a SG of 1 and a dry weight of 0.25 times wet weight. This distribution is compared with an average species size distribution curve for sublittoral benthic communities, which has been constructed from the mean parameter values of the 4 sublittoral communities studied so far: Northumberland, Carmarthen Bay, Algoa Bay (Warwick 1984) and Stn CS2 (this study). The log-normal distribution of egg size is closely similar to that of the 
adult meiofauna (Fig. 4). Larvae hatching from these egg cases will have the same size distribution as the eggs themselves, and Warwick (1984) has shown that they grow to a maximum size which corresponds with the trough in the benthic species size distribution, or the peak in the pelagic size distribution, before settling to the bottom. If they remained on the bottom, the newly hatched larvae would find niches for this size of

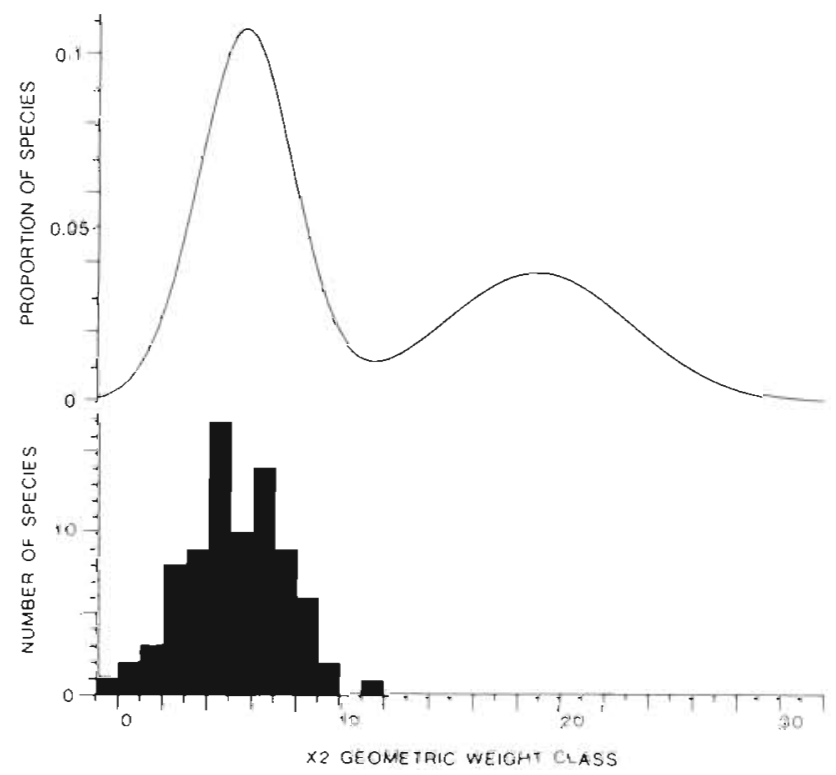

Fig. 4. Histogram of size distribution of eggs of macrobenthic species which have planktotrophic larvae, compared with a generalised benthic species body size distribution curve

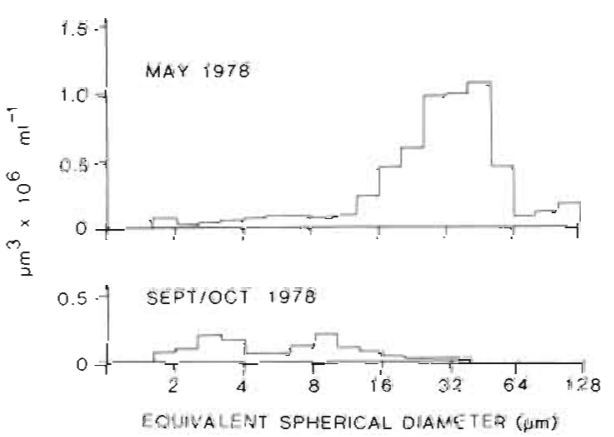

Fig. 5. Histograms of size distributions of phytoplankton cells (determined by Coulter counter) from the Celtic Sea during the Spring bloom and in the Autumn (from $\mathrm{H}$. H. Bottrell unpubl. data)

animal occupied by the meiobenthos which, because of their high diversity and variety of narrowly specialised feeding mechanisms (Warwick 1981), comprise a highly efficient consumer unit. Similarly, the larvae settle to the bottom at a size when they would begin to compete with the holoplankton. Thorson (1946) points out that by far the majority of these macrobenthic larvae feed on phytoplankton in the smaller size range ( 2 to $30 \mu \mathrm{m}$ ), and furthermore that in the Oresund the number of species in the plankton reaches peak abundance in September/October rather than at the time of the spring phytoplankton bloom. In the Celtic Sea, the phytoplankton in the Autumn comprises mainly naked flagellates and dinoflagellates in the 2 to $16 \mu \mathrm{m}$ size range, whereas the spring bloom is dominated by diatoms in the 16 to $64 \mu \mathrm{m}$ range (Fig. 5), which are preferentially grazed by calanoid copepods (H. H. Bottrell unpubl.). It would not seem unreasonable, therefore, to invoke temporal resource partitioning on a size basis between the meroplankton and holoplankton as a factor contributing to the low number of small holoplanktonic species. Lecithotrophic larvae will, of course, not be involved in this partitioning, and species with this type of development have been omitted from our analysis of egg sizes.

It is not only competition for food with the meiobenthos which may render the benthos inhospitable to the young larvae of macroinvertebrates, but also predation by the meiobenthos on such larvae which may be potentially intense. Christensen (quoted by Thorson 1966) observed that the very youngest spat of the bivalve Spisula elliptica were attacked and eaten in large quantities' by meiobenthic nematodes, although the older spat were not susceptible. Even older planktotrophic larvae, at the time of settlement to the bottom, are subjected to significant predation by the larger members of the meiobenthos (Watzin 1983, 1986). Invertebrate eggs and embryos are generally negatively buoyant and incapable of keeping themselves off the bottom, and predation pressure has been invoked in the selection for 'mixed' life histories of macrobenthic species, with capsules or egg masses retaining vulnerable embryos until they are capable of swimming away from the bottom (Pechenik 1979).

The above scenario is consistent with current opinion of the significance of planktotrophic larval phases in the life-histories of marine macrobenthic species. Strathmann (1985) speculates that the planktotrophic larval phase may be viewed as a migration into the plankton for feeding and safety: dispersal is an accidental by-product but it is not selection for dispersal that maintains a feeding larval stage in life histories. Our observations provide some insight into why feeding and safety conditions are more favourable in the water column than on the bottom for these larvae, and suggest that interaction with the meiofauna over an evolutionary time-scale may have played a significant part in shaping the life-history patterns of macrobenthic animals. As Strathmann (1985) has pointed out, life-history theories for marine animals cannot ignore a strong historical component stretching back to the origin of the Metazoa. 


\section{Influence of pelagic community on benthic food supply}

The possibility that the pelagic community might preferentially graze parts of the phytoplankton size spectrum before it arrives on the bottom may be a selective force in the evolution of body sizes in the benthic community. In this connection it is instructive to examine the species size distributions of benthic communities in which the component species have not evolved under the pressures of this interaction. One such case is in communities which are highly organically enriched with non-phytoplankton particulate material, which comprise a characteristic group of 'pollution indicator' species. Those species which occur in very large numbers under such conditions, but which are relatively rare in unenriched communities, are the opportunistic (r) species rather than the pollution tolerant $(\mathrm{T})$ species according to the classification of Gray (1979). These are listed in Table 1, together with an estimate of their adult body size. It is well

Table 1. Adult dry weights of species which become very abundant in organically enriched habitats

\begin{tabular}{|c|c|c|c|}
\hline Species & Source & $\begin{array}{l}\text { Dry wt. } \\
(\mu \mathrm{g})\end{array}$ & $\begin{array}{l}\text { Source } \\
\text { of } d . w t .\end{array}$ \\
\hline \multicolumn{4}{|l|}{ Annelids } \\
\hline Capitella capitata & 1,2 & 505 & 3 \\
\hline Polydora ciliata"/ligni & 1,2 & $125^{\circ}$ & 4 \\
\hline $\begin{array}{l}\text { Streblospio benedictil } \\
\text { shrubsoli. }\end{array}$ & 1,2 & $188^{\circ}$ & 4 \\
\hline Peloscolex benedeni & 1,2 & 306 & 4 \\
\hline Ophryotrocha hartmanni & 5 & 50 & 5 \\
\hline Ophryotrocha puerilis & 6 & 140 & 5 \\
\hline Raphidrilus sp. & 6 & 158 & 6 \\
\hline Protodorvillea kefersteini & 1,3 & 108 & 3 \\
\hline Pholoe minuta & 3 & 190 & 3 \\
\hline \multicolumn{4}{|l|}{ Nematodes } \\
\hline Metoncholaimus albidus & 7,8 & 12 & 9 \\
\hline M. scanicus & 10 & 23 & 9 \\
\hline Pontonema sp. & 7 & 64 & 9 \\
\hline \multicolumn{4}{|l|}{ Copepods } \\
\hline Tisbe spp. & 11 & 12 & 9,12 \\
\hline Bulbamphiascus imus & 11 & 3 & 9 \\
\hline \multicolumn{4}{|c|}{$\begin{array}{l}\text { Sources of information: (1) Pearson \& Rosenberg (1978); } \\
\text { (2) Gray (1979); (3) Pearson (1975); (4) reference speci- } \\
\text { mens from Tamar estuary; (5) Tennant (1985); (6) North } \\
\text { Sea oil rigs (P. Kingston pers, Comm.); (7) Clyde Sea } \\
\text { sewage sludge dumping ground (B. Bett pers. comm.); (8) } \\
\text { Stonehouse pool, Tamar estuary, with Ophryotrocha hast- } \\
\text { manni (R. M. Warwick unpubl.); (9) estimated from vol- } \\
\text { ume determinations (Warwick \& Gee 1984); (10) English } \\
\text { Channel off Calais (R. C. Newell unpubl. report); (11) } \\
\text { Hicks \& Coull (1983); (12) for an average sized species, T. } \\
\text { gracilis }\end{array}$} \\
\hline
\end{tabular}

known that the macrofaunal taxa in organically polluted areas are confined to a few species of annelids at the lower end of the macrobenthic size range (Pearson \& Rosenberg 1978), which are capable of direct benthic development, and there is no shortage of theoretical arguments explaining this phenomenon. However, none of these arguments account for the fact that, among the meiofaunal taxa, it is often the very largest species which are favoured under such conditions, and which become overwhelmingly dominant both numerically and in terms of biomass. These are nematodes of the family Oncholaimidae and copepods of the families Tisbidae (many sibling species of Tisbe often occurring together in large numbers) and Diosaccidae. Each locality only accomodates a small number of these species, and we have put the data from a number of localities together to construct an idealised 'enrichment community'. This community has a size distribution occupying the trough in normal benthic communities, and corresponding closely to the species size distribution of the CS2 pelagic community (Fig. 6), although it is slightly biased towards large-

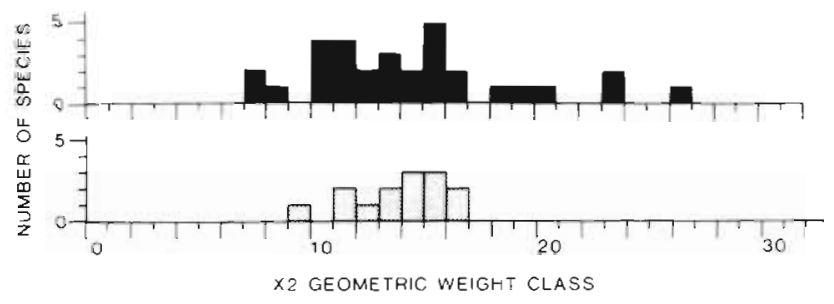

Fig. 6. Size distribution of species characteristic of nutrient enriched communities, from Table 1, (lower stippled histogram) compared with the species size distribution of Stn CS2 pelagic organisms (upper solid histogram)

sized species since macrofaunal taxa have been more thoroughly investigated in the pollution context than meiofaunal taxa. We submit that this convergence of macrofauna and meiofauna to a single optimum size can be explained by the absence of coupling with the pelagic system. This would imply that the size distribution of 'normal' Shelf communities has been influenced by such coupling. Coupling between the 2 systems may also break down in the deep sea, where physical distance precludes it. Here there is also evidence of convergence in size of macrofauna and meiofauna species (Thiel 1975), although no formal species size distributions have yet been compiled.

Size convergence in 'enrichment communities' may, however, have alternative explanations. In such situations macrobenthos and meiobenthos may be subjected to different selection pressures. Gray (1979) summarises the macrofaunal adaptations, but for the meiofauna the highly specialised feeding behaviour of 
smaller species may not be favoured under conditions of organic enrichment, and large generalists will be more successful. Oncholaimid nematodes are classified as omnivores (Wieser 1953) and tisbid copepods have very catholic diets (review by Hicks \& Coull 1983). It is interesting to note that, like the macrobenthos (Gray 1979), the meiobenthos has a very restricted taxonomic composition, but those species which do occur comprise groups of very closely related species (sibling species of Tisbe and closely related species of oncholaimid nematodes).

The above discussion of benthic/pelagic interactions is speculative and our hypotheses regarding evolutionary constraints on body size are largely untestable. However, an investigation of present day mechanisms of interaction, of the kinds indicated above, would add weight to the argument that they have acted as evolutionary forces in the past. Because of their potential importance to the trophodynamics and community structure of both the benthic and pelagic realms, an integrated effort to investigate these interactions would be timely.

Acknowledgements. We are grateful to Howard Bottrell for allowing us to use his unpublished data on phytoplankton size distributions. Jan Pechenik and Lindy Eyster made helpful suggestions for improving the manuscript. This work forms part of the community ecology programme of the Institute for Marine Environmental Research, a component of the Natural Environment Research Council.

\section{LITERATURE CITED}

Beverton, R. J. H., Tungate, D. S. (1967). A multi-purpose plankton sampler. J. Cons. perm. int. Explor. Mer 31: 145-157

Clarke, K. R. (1984). Parameter estimation for mixture distributions of species size. Oecologia (Berl.) 61: 40-41

Craib, J. S. (1965). A sampler for taking short undisturbed marine cores. J. Cons. perm. int. Explor. Mer 30: 34-39

Gray, J. S. (1979). Pollution-induced changes in populations Phil. Trans. R. Soc. B 286: 545-561

Harding, D., Arnold, G. P. (1971). Flume experiments on the hydrodynamics of the Lowestoft high-speed plankton samplers: I. J. Cons. int. Explor Mer. 34: 24-36

Hessler, R. R., Jumars, P. A. (1974). Abyssal community analysis from replicate box cores in the central North Pacific. Deep Sea Res. 21: 185-209

Hicks, G. R. F., Coull, B. C. (1983). The ecology of marine meiobenthic harpacticoid copepods. Oceanogr. mar. Biol. A. Rev. 21:67-175

Koehl, M. A. R., Strickler, J. R. (1981). Copepod feeding currents: food capture at low Reynolds number. Limnol. Oceanogr. 26: 1062-1073
McIntyre, A. D., Warwick, R. M. (1985). Meiofauna techniques. In: Holme, N. A., Mclntyre, A. D. (ed.) Methods for the study of marine benthos. IBP Handbook No. 16 (2nd edn). Blackwell, Oxford, p. 217-244

Palmer, M. A. (1984). Invertebrate drift. Behavioral experiments with intertidal meiobenthos. Mar. Behav. Physiol. 10: 235-253

Palmer, M. A., Gust, G. (1985). Dispersal of meiofauna in a turbulent tidal creek. J. mar. Res. 43: 179-210

Pearson, T. H. (1975). The benthic ecology of Loch Linnhe and Loch Eil, a sea-loch system on the West coast of Scotland. IV. Changes in the benthic fauna attributable to organic enrichment. J. exp. mar. Biol. Ecol. 20: 1-41

Pearson, T. H., Rosenberg, R. (1978). Macrobenthic succession in relation to organic enrichment and pollution of the marine environment. Oceanogr. mar. Biol. A. Rev. 16: 229-311

Pechenik, J. A. (1979). Role of encapsulation in invertebrate life histories. Am. Nat. 114: 859-870

Schwinghamer, P. (1985). Observations on size-structure and pelagic coupling of some shelf and abyssal benthic communities. In: Gibbs, P. E. (ed.) Proceedings of the 19th European Marine Biology Symposium. Cambridge University Press, Cambridge, p. 347-359

Sheldon, R. W., Prakash, A., Sutcliffe, W. H., Jr. (1972). The size distribution of particles in the ocean. Limnol Oceanogr. 17: 327-340

Strathmann, R. R. (1985). Feeding and nonfeeding larval development and life-history evolution in marine invertebrates. Ann. Rev. Ecol. Syst. 16: 339-361

Tennant, V. A. (1985). Energy partitioning and reproductive strategies in four species of the meiofaunal polychaete genus Ophryotrocha. Ph. D. thesis, University of Exeter

Thiel, H. (1975). The size structure of the deep-sea benthos. Int. Revue ges. Hydrobiol. 60: 575-606

Thorson, G. (1946). Reproduction and larval development of Danish marine bottom invertebrates. Meddr Kommn. Danm. Fisk.-og Havunders. ser. Plankton 4: 1-523

Thorson, G. (1966). Some factors influencing the recruitment and establishment of marine benthic communities. Neth J. Sea Res. 3: 267-293

Warwick, R. M. (1981). Survival strategies of meiofauna. In: Jones, N. V., Wolff, W. J. (ed.) Feeding and survival strategies of estuarine organisms. Plenum, New York, p. $39-52$

Warwick, R. M. (1984). Species size distributions in marine benthic communities. Oecologia (Berl.) $61: 32-41$

Warwick, R. M., Gee, J. M. (1984). Community structure of estuarine meiobenthos. Mar. Ecol. Prog. Ser. 18: 97-111

Watzin, M. C. (1983). The effects of meiofauna on settling macrofauna: meiofauna may structure macrofauna communities. Oecologia (Berl.) 59: 163-166

Watzin, M. C. (1986). Larval settlement into marine softsediment systems: interactions with the meiofauna. J. exp. mar. Biol. Ecol. 98: 65-113

Wieser, W. (1953). Die Beziehung zwischen Mundhöhlengestalt, Ernährungsweise und Vorkommen bei freilebenden marinen Nematoden. Ark. Zool. Ser. 2, 4: 439-484

Williams, R., Collins, N. R. (1986). Seasonal composition of meroplankton and holoplankton in the Bristol Channel. Mar. Biol. 92: 93-101 